\title{
Doeltreffende keuringsonderhoude: Die taak van lynbestuur
}

\author{
David Tromp \\ Universiteit van Stellenbosch Bestuurskool, Bellville
}

\begin{abstract}
Effective selection interviews: The task of line management. The selection interview still remains one of the most important and most commonly used selection techniques. During their formal training personnel officials are normally taught how to conduct selection interviews in a professional and effective way. However, the final responsibility for the selection decision still rests with the line manager but he often lacks the skills necessary to conduct a good selection interview. The result of this is that a highly intuitive and risky decision is taken.

In this article the most important errors which interviewers make, are discussed. These errors relate in the first instance to the way in which selection interviews are conducted and the resulting shortcomings in communication which have a negative effect on the availability of the information required for decision-making. Secondly, errors are often made in respect of the interpretation and evaluation of this information. A procedure for eliminating these errors is proposed of which the main components are a semistructured approach and the use of an interview appraisal form based on the prior identification of the required behavioural dimensions.
\end{abstract}

S. Afr. J. Bus. Mgmt. 1982, 13: $197-204$

Die keuringsonderhoud bly steeds een van die belangrikste en gewildste keuringstegnieke. Personeelbeamptes ontvang gewoonlik gedurende hulle formele opleiding onderrig in die voer van doeltreffende keuringsonderhoude. Die finale besluit by keuring bly egter steeds die verantwoordelikheid van lynbestuur maar dikwels beskik so 'n bestuurder nie oor die nodige vaardighede om self ' $n$ goeie keuringsonderhoud te voer nie, met die gevolg dat hy dan 'n hoogs intuïtiewe en riskante besluit neem.

In hierdie artikel word die belangrikste foute wat deur onderhoudvoerders gemaak word, bespreek. Hierdie foute hou in die eerste plek verband met die wyse waarop

keuringsonderhoude gevoer word en die

kommunikasietekortkominge wat so ontstaan met die gevolg dat onvoldoende toepaslike inligting bekom word. In die tweede plek word verskeie foute gemaak by die interpretering en evaluering van die verkreë inligting met die gevolg dat swak keuringsbesluite geneem word. 'n Prosedure met betrekking tot onderhoudvoering word voorgestel waarin 'n semi-gestruktureerde benadering en 'n beoordelingsvorm, gebaseer op ' $n$ vooraf identifisering van verlangde gedragsdimensies, 'n belangrike onderdeel vorm.

S.Afr. Tydskr. Bedryfsl. 1982, 13: $197-204$

Dr. D. Tromp

Universiteit van Stellenbosch Bestuurskool, Posbus 610, Bellville 7530.

Republiek van Suid-Afrika

Ontvang Mei 1982; aanvaar Augustus 1982

\section{Inleiding}

Elke bestuurder moet oor die finale verantwoordelikheid, aanspreeklikheid en gesag met betrekking tot sy eie personeel beskik, gewoonlik binne die raamwerk van die personeelbeleid van die organisasie waaraan hy verbonde is. Alhoewel hy dikwels kan staatmaak op professionele hulp en advies van personeelbeamptes, beskik hy gewoonlik oor die gesag om die finale besluit te neem ten opsigte van dié applikante wat hy vir 'n vakante pos in sy departement gaan aanstel. Daarom is hy ook verantwoordelik daarvoor om die beste besluit te neem en moet hy sorg dra dat hy oor die inligting beskik wat nodig is om dit te kan doen. Hierdie is dus ' $n$ taak wat hy ongelukkig nie geheel en al op sy personeelbeampte kan afskuif nie.

Die onderhoud bly steeds 'n baie gewilde tegniek om inligting vir keuringsdoeleindes te bekom. So byvoorbeeld beweer Michaels ${ }^{1, p p .199-200}$ dat hy van geen keuringsbattery weet wat nie ' $n$ onderhoud met applikante insluit nie. Ook Flippo $^{2, p .143}$ spreek die mening uit dat die onderhoud waarskynlik die enkele keuringstegniek is wat die wydste toepassing geniet.

In die Amptelike Jaarboek van die Republiek van Suid-Afrika ${ }^{3}$ word gerapporteer dat Suid-Afrika se totale ekonomies-bedrywige bevolking in 1980 sowat 6,3 miljoen mense beloop het. Volgens 'n ondersoek deur Bendix en Swart ${ }^{4}$ het arbeidsomset in die privaatsektor op sowat $22,2 \%$ te staan gekom terwyl daar in dieselfde jaar ongeveer $14,0 \%$ nuwe poste geskep is. Indien hierdie syfers beskou word as van toepassing op die totale ekonomies-bedrywige bevolking van Suid-Afrika, impliseer dit dat 2,3 miljoen werknemers gedurende 1980 as gevolg van vervanging van diensverlaters of as gevolg van uitbreiding van indiensneming, gekeur en aangestel is. Indien daar deur twee verteenwoordigers van die werkgewer, met elkeen van hulle sowel as met ten minste twee ander applikante onderhoude gevoer is van ten minste 30 minute elk, is daar sowat 8 miljoen keuringsonderhoude gevoer wat sowat 8 miljoen man-ure van bestuurders en personeelbeamptes in beslag geneem het.

Tog word die sukses van die onderhoud, soos uitgedruk in terme van voorspellingsgeldigheid, deur verskeie navorsers op grond van empiriese studies sterk bevraagteken (Drake $^{5, p p .5-6}$ en Dunnette ${ }^{6 . p .10}$ ). Albei hierdie skrywers skryf egter nie die gebrek aan voorspellingsgeldigheid by die keuringsonderhoud toe aan die onderhoud as tegniek nie, maar 
wel aan die gebrekkige inligting op grond waarvan onderhoudvoerders hulle besluite neem omdat hulle dikwels nie oor voldoende opleiding beskik om die onderhoud as keuringstegniek behoorlik te hanteer nie.

Indien die sukses van die onderhoud as keuringstegniek soos dit tans in Suid-Afrika aangewend word, optimisties op $75 \%$ geskat word, bring dit mee dat by 2 miljoen van die 8 miljoen onderhoude waarna hierbo verwys is, verkeerde besluite geneem is. Dit bring ' $n$ vermorsing van mannekrag mee wat Suid-Afrika en die verskillende werkgewer-organisasies nie kan bekostig nie.

Die tyd het dus reeds aangebreek dat bestuurders en personeelbeamptes wat betrokke is by onderhoudvoering hulleself afvra of die wyse waarop hulle hierdie belangrike mannekragbestuurstegniek hanteer, reg laat geskied aan die doel daarvan. Orpen ${ }^{7, p p .60-61}$ wys tereg daarop dat onderhoudvoerders gewoonlik 'n groot (en soms blinde) geloof het in die prentjie wat hulle vir hulleself opbou omtrent applikante en geneig is om empiriese geldigheidstudies en betroubaarheidstudies as oorbodig te beskou. Die onderhoud is 'n subjektiewe tegniek waartydens ' $n$ intuitiewe regressie-vergelyking deur die onderhoudvoerder opgebou word deurdat hy eerstens data omtrent die applikant insamel deur middel van vrae wat hy self uitdink (Orpen ${ }^{7, p .61}$ ). Daarna evalueer en weeg hy hierdie data op grond van sy gevoel omtrent die toepaslikheid daarvan, waarna hy 'n intuïtiewe voorspelling van die applikant se latere werksgedrag maak. Subjektiwiteit as sulks is onvermydelik en hoef nie noodwendig ' $n$ verskoning te wees vir swak onderhoude nie. Daar is verskeie stappe wat onderhoudvoerders kan neem om te verseker dat hulle soveel moontlik toepaslike inligting bekom omtrent die vakature en die applikante ten einde meer geldige indiensnemingsbesluite te kan neem.

\section{Die doel van die keuringsonderhoud}

Die doel van die keuringsonderhoud word tradisioneel gesien as die insameling van inligting omtrent ' $n$ applikant met die oog op die voorspelling van latere werksukses. Wanous ${ }^{8, p .141}$ wys in hierdie verband daarop dat die doel van die onderhoud hoofsaaklik is om te bepaal in welke mate die applikant se vermoëns inpas by die vereistes van die vakante pos, asook in watter mate die applikant se persoonlike behoeftes in ooreenstemming is met die organisatoriese klimaat. Hy noem voorts dat navorsing aan die lig gebring het dat die onderhoud nie 'n baie goeie metode is om vermoëns van applikante te meet nie, maar dat dit wel met sukses gebruik kan word om applikante se persoonlike behoeftes te bepaal.

'n Verdere doel van die keuringsonderhoud is die bekendstelling en bemarking van die werkgewerorganisasie. Keuring bly ' $n$ tweerigtingproses en dit is belangrik dat die suksesvolle applikant ook 'n begeerte ondervind om by die betrokke onderneming aan te sluit. Wanous ${ }^{8, p p .106-108}$ rapporteer ' $n$ studie by die Cornell Universiteit waartydens bevind is dat $112 \mathrm{MBA}$-studente te kenne gegee het dat 'n goeie onderhoud hulle bereidwilligheid om 'n pos te aanvaar, verhoog het. Faktore wat in hierdie opsig deurslaggewend was, is die gedrag sowel as die houding van die onderhoudvoerder.
Dit wil dus voorkom asof die keuringsonderhoud daarop ingestel moet wees om eerstens applikante te identifiseer wat beskik oor die kennis, vaardighede en houding wat vereis word deur die vakante pos binne die raamwerk van die algemene organisatoriese klimaat en om tweedens die behoefte by sodanige applikante te skep om ' $\mathrm{n}$ aanbod wat uit die onderhoud sou voortspruit, te aanvaar.

Wat die keuringsfunksie van die onderhoud betref, noem Cascio en $\mathrm{Awad}^{9}$ dat die onderhoud nie net daarop ingestel moet wees om die geskikste applikante aan te stel of die niegeskikte applikante te verwerp nie, maar ook om te verhoed dat geskikte applikante verwerp word. Ook Dunette ${ }^{6, p .7-8}$ wys daarop dat daar by keuring onderskei moet word tussen foutiewe voorspelling van werksukses en foutiewe voorspelling van werksmislukking en hy verwys in hierdie opsig onderskeidelik na 'false positive error' en 'false negative error'. Cascio en Awad ${ }^{9}$ propageer in hierdie verband 'n besluitnemingsteorie-benadering waarvolgens die sukses van die keuringsonderhoud gemeet moet word aan die hand van die verhouding tussen die korrekte en die foutiewe keuses waar korrekte en foutiewe aanvaardings sowel as korrekte en foutiewe verwerpings in berekening gebring word.

Die voordeel van so 'n besluitnemingsteorie-benadering is dat dit die onderhoudvoerder dwing om alle oordele wat hy moet vel, eksplisiet te oorweeg. So byvoorbeeld kan 'n probleem van foutiewe aanvaardings voorkom word deur die standaard wat ten opsigte van die voorspeller bereik moet word, te verhoog. Dit het egter ook 'n verhoging in die aantal foutiewe verwerpings tot gevolg wat meebring dat meer applikante gewerf moet word en so 'n besluit het dus implikasies met betrekking tot die werwingspoging.

\section{Foute wat oor die algemeen deur onderhoudvoerders gemaak word}

Die redes waarom die onderhoud dikwels nie aan sy doel beantwoord as keuringstegniek nie, het in die eerste plek te make met die onvermoë van die onderhoudvoerder om tydens die onderhoud voldoende toepaslike inligting van die applikant te verkry, asook om hierdie inligting korrek te interpreteer in terme van die posvereistes. In die tweede plek beskik die applikante nie altyd oor voldoende inligting om te kan besluit of hulle hul beroepsbehoeftes in die betrokke pos en by die betrokke werkgewer sal kan bevredig nie. 'n Interessante benadering in hierdie verband is dié van Latterell, ${ }^{10, p p .466-480}$ wat van die bekende Johari-venster gebruik maak om aan te toon dat die onderhoud soos enige ander kommunikasietegniek, sodanig toegepas moet word dat die arena-gebied (kyk Figuur 1) so groot as moontlik is. Hierdie arena-gebied bevat die inligting wat aan die onderhoudvoerder sowel as die applikant goed bekend is.

Hoe groter die arena-gebied egter, hoe beter moet die onderhoudvoerder in staat wees om toepaslike inligting te identifiseer en te interpreteer in terme van die vereistes van die vakante pos. Hoe kleiner die arena-gebied egter, hoe groter is die kans dat belangrike inligting aan een van die partye (die onderhoudvoerder of die applikant) onbekend bly en hoe groter dus die kans vir 'n foutiewe besluit met betrekking tot die maak van 'n aanbod deur die onderhoudvoerder, sowel as die aanvaarding daarvan deur die applikant. 
Inligting waaroor applikant beskik

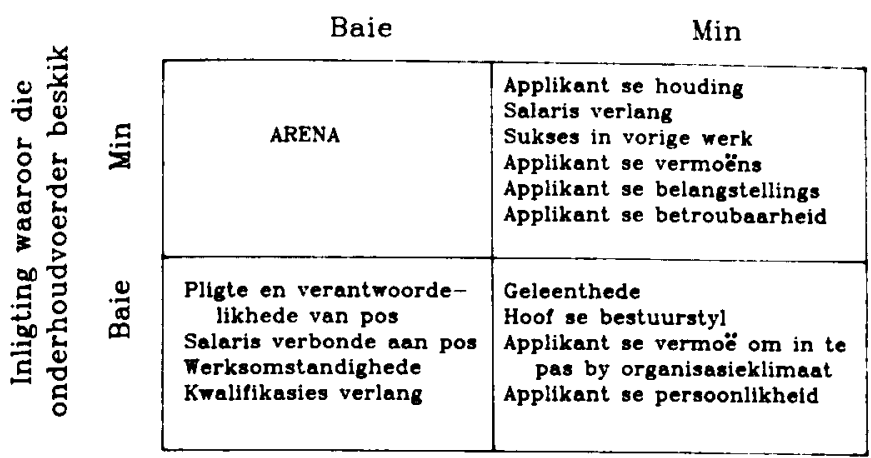

Figuur 1 Die Johari-venster soos van toepassing op die keuringsonderhoud (Latterell ${ }^{10}$ )

Foute wat oor die algemeen gemaak word deur onderhoudvoerders wanneer hulle applikante evalueer en wat dus die doeltreffendheid van die onderhoud as keuringstegniek kan benadeel, is die volgende:

- Eerste indrukke speel 'n te groot rol in die finale besluit. Schmitt ${ }^{11, p .268}$ verwys na ondersoeke deur Blakeney en MacNaughton asook deur Peters en Terborg wat bevestig dat onderhoudvoerders hulle in 'n groter mate laat lei deur inligting wat vroeg in die onderhoud na vore kom as deur inligting wat later verstrek word. Wanous $^{8, p .142}$ verwys na hierdie verskynsel as die 'primacy effect' en rapporteer studies wat aangetoon het dat die gemiddelde onderhoudvoerder reeds na $1 j$ minute 'n besluit neem oor die applikant. Hy wys egter daarop dat hierdie verskynsel ook van toepassing is op die persoon met wie die onderhoud gevoer word.

- Negatiewe inligting word as hoogs betekenisvol beskou. Byham $^{12}$ asook Schmitt ${ }^{11, p .267-268}$ beweer dat die onderhoudvoerder makliker sal sê waarom 'n betrokke applikant nie geskik is nie, as waarom hy wel geskik is vir 'n sekere pos. Schmitt ${ }^{11, p p .267-268}$ baseer hierdie bewering op empiriese ondersoeke van onder andere Springbett, asook Bolster en Springbett en Hollman. Ook Wanous ${ }^{8, p .142}$ bevestig hierdie verskynsel en rapporteer dat 'n ondersoek wat hy onderneem het, aangetoon het dat $90 \%$ van alle verwerpings op grond van die onderhoud aan een enkele brokkie negatiewe inligting toegeskryf kon word.

- Vooropgestelde idees van onderhoudvoerders bring mee dat hulle gewoonlik soek na 'n ideale persoon vir 'n betrokke pos. Byham ${ }^{12}$ sowel as Schmitt ${ }^{11, p p .271-272}$ verwys na hierdie verskynsel as die stereotipe-effek. Die probleem hieraan verbonde is dat daar nie altyd 'n ideale persoon vir 'n betrokke pos bestaan nie. Dunnette $e^{6, p p \cdot 10-11}$ wys in hierdie opsig daarop dat individue nie net onderling verskil nie, maar ook binne hulleself en dat daar dus nie applikante sal wees wat aan al die vereistes vir 'n pos voldoen en geen swakpunte het nie. Posbekleërs wat aansienlik van mekaar verskil ten opsigte van verskeie persoonlike kenmerke, is dikwels ewe suksesvol in dieselfde soort pos. Verder moet onderhoudvoerders in gedagte hou dat verskeie van hierdie persoonlike kenmerke wel veranderbaar is en dat sekere tekortkominge wel deur middel van opleiding en ondervinding reggestel kan word.

- Individuele kenmerke van onderhoudvoerders beinvloed hulle beoordelings van applikante. Bestuurders en personeelbeamptes wat onderhoude voer verskil ook onderling ten opsigte van 'n wye reeks veranderlikes waaronder veral houdings ' $n$ belangrike rol speel. Schmitt ${ }^{11, p p .272-274}$ verwys na ondersoeke deur Baskett, asook Peters en Terborg, en Rand en Wexley waartydens bevind is dat ooreenstemmende houdings tussen die applikant en die onderhoudvoerder tot hoër beoordelings aanleiding gegee het. Voorts wys hy daarop dat Dobmeyer, asook Valenzi en Andrews, en Rowe bevind het dat onderhoudvoerders verskil met betrekking tot die gewig wat hulle aan bepaalde response van applikante heg op grond van hul eie houdings en voorkeure. Hierdie verskille word dikwels nie op 'n rasionele wyse deur onderhoudvoerders deurdink en deurgepraat voordat ' $n$ finale besluit oor 'n applikant geneem word nie.

- Onderhoudvoerders is nie altyd goed voorberei vir die onderhoud nie. Byham ${ }^{12}$ wys daarop dat onderhoudvoerders nie altyd na al die nodige inligting soek wanneer hulle onderhoude voer nie en dat hulle dikwels oorvleuel ten opsigte van die dekking van verskeie aspekte. Die betrokke bestuurder en sy personeelbeampte versuim baiekeer om saam vooraf te bepaal na watter inligting hulle gaan soek en wie watter vrae gaan vra. Hierdie gebrek aan voorafbeplanning bring dikwels ook mee dat leidende vrae gevra word of vrae wat slegs met ' $n$ 'ja' of ' $n$ 'nee' beantwoord word. Dit gebeur ook baiemaal dat bestuurders as gevolg van swak voorbereiding vrae vra wat slegs neerkom op 'n herhaling van dit wat die applikant reeds in die aansoekbrief of op die aansoekvorm aangegee het. 'n Verdere tekortkoming is dat die onderhoudvoerders in baie gevalle te veel praat en vroeg in die onderhoud te veel inligting aan die applikant verstrek omtrent die pos en die organisasie, wat meebring dat hy sy antwoorde kan aanpas tot dit wat verlang word.

- Ander faktore wat volgens Schmitt ${ }^{11, p p .265-283}$ en Flippo $^{13}$ die beoordeling van applikante tydens die onderhoud beïnloed, is die aantal vakatures en die druk om 'n pos te vul, asook die kennis van die applikant omtrent die inhoud en vereistes van die vakante pos. Schmitt ${ }^{11, p .273}$ noem verder dat Dittman en Ekman albei, asook Matarazzo, Wiens en Saslow deur middel van ondersoeke bevind het dat sigbare tekens tydens die onderhoud soos voorkoms, houding, ensovoorts, 'n groter invloed as verbale response op die finale keuringsbesluit uitoefen.

Die uitskakeling van bogenoemde foute wat deur onderhoudvoerders gemaak word, is volgens Dunette $\mathrm{e}^{6 . p p .7-8}$ nie net vir hoëvlakposte van kritiese belang nie, maar ook vir laervlakposte. Hy wys daarop dat onderhoudvoerders dikwels minder aandag gee aan goeie onderhoudvoering wanneer personeel op laer vlakke gekeur word, maar dat dit ernstige koste-implikasies vir werkgewers kan inhou vanweë die groot getalle wat ter sake is. 


\section{'n Prosedure vir beter onderhoude en beter keuringsbesluite}

Onderhoude wat op 'n professionele wyse gevoer word, sal nie net die keuringsbesluit deur die onderhoudvoerder verbeter nie, maar ook 'n meer positiewe beeld van die werkgewer aan die applikant oordra. Dit is dus belangrik dat die prosedure en tegnieke van onderhoudvoering voorsiening maak vir effektiewe onderhoudvoering sowel as effektiewe besluitneming. In hierdie verband word drie opeenvolgende fases aanbeveel, naamlik voorbereiding, die voer van die onderhoud en die evaluering van die applikant.

\section{Voorbereiding vir die onderhoud}

Deeglike kennis omtrent die posvereistes is nodig. Dessler ${ }^{13, p .86}$ verwys na ondersoeke deur Longdale en Wertz waartydens bevind is dat 'n groep onderhoudvoerders wat vooraf meer volledige inligting omtrent 'n vakante pos ontvang het, 'n groter mate van ooreenstemming getoon het ten opsigte van hulle beoordeling van applikante as onderhoudvoerders wat slegs 'n baie beknopte opsomming en minder volledige inligting ontvang het. Laasgenoemde groep het ook oor die algemeen hoër beoordelingstellings gegee. Dat ' $n$ toename in inligting omtrent ' $n$ vakante pos 'n hoër mate van interbeoordelaar-betroubaarheid tot gevolg het, is ook bevestig deur middel van ondersoeke deur Longdale en Weitz, asook deur Weiner en Schneiderman (Schmitt $^{11, p .272}$ ).

'n Volledige posbeskrywing moet dus vooraf beskikbaar gestel word aan alle persone wat as onderhoudvoerders betrokke sal wees by die vul van 'n pos. Die verantwoordelike personeelbeampte behoort dan die onderhoudvoerders byeen te bring vir ' $n$ voorbereidende sessie waartydens die verskillende sleutel-aktiwiteite in die pos geidentifiseer en gegroepeer word aan die hand van die posbeskrywing. Dit is moontlik dat daar op hierdie stadium gewigte toegeken kan word aan die verskillende sleutelaktiwiteite op grond van hulle relatiewe belangrikheid. Die opstel van 'n lang en volledige posbeskrywing is nie 'n voorvereiste nie en waar dit nie bestaan nie, kan die onderhoudvoerders volgens Dunnette ${ }^{6 . p p .68-88}$ hierdie lys sleutelaktiwiteite van meet af opstel. Hy wys ook daarop dat inligting omtrent sleutelaktiwiteite gedragsgeoriënteerd moet wees, dat daar onderskei moet word tussen statiese en dinamiese kenmerke van 'n pos, asook dat daar ten opsigte van die dinamiese kenmerke voorsiening gemaak moet word vir verandering wat deur die tyd, die situasie en deur die werknemer bepaal word. Dit is dus belangrik dat die pos beskryf word aan die hand van dit wat tans bestaan sowel as verwagte veranderinge in die posinhoud.

Die volgende stap vir die onderhoudvoerders is om 'n manspesifikasie op te stel deur die posvereistes te herlei na dié gedragsdimensies wat nodig is om die sleutelaktiwiteite te kan uitvoer. Hierdie gedragsdimensies sluit volgens Hollandsworth, Kazelskis, Stevens en Dressel, ${ }^{14}$ verbale sowel as nie-verbaie persoonlike kenmerke in wat as sulks tydens die onderhoud geïdentifiseer kan word. Soos reeds genoem, is 'n probleem in hierdie verband dat daar gewoonlik na ' $n$ ideale persoon gesoek word en dat onderhoudvoerders dikwels onderling verskil in hulle siening van so 'n persoon. Sodanige verskille moet op hierdie stadium bespreek word en eenstemmigheid moet bereik word ten opsigte van die verlangde gedragsdimensies eerder as ten opsigte van 'n ideale totale persoonlikheid. Ook op hierdie stadium reeds moet daar bepaal word watter inligting teen 'n hoër vlak van betroubaarheid uit ander bronne soos byvoorbeeld verwysings en psigometriese toetse verkry kan word. Byham ${ }^{12}$ waarsku tereg teen die neiging van bestuurders om te swaar op die onderhoud te leun as bron van inligting vir keuringsbesluite.

Daar moet ook daarteen gewaak word om die vereistes ten opsigte van die gedragsdimensies te hoog te stel. Bestuurders wil gewoonlik oor ' $n$ bekwame span ondergeskiktes beskik, maar daar moet in gedagte gehou word dat persone wat byvoorbeeld te hoog gekwalifiseerd is vir ' $n$ pos, maklik gefrustreerd sal raak indien hulle potensiaal nie benut word nie. Hoër gekwalifiseerde applikante of applikante met beter ontwik kelde vaardighede op grond van langer werkservaring sal waarskynlik ook hoër vergoedingseise stel wat dan onewewigtighede in bestaande vergoedingstrukture kan meebring.

Die volgende stap in die voorbereidingsfase is om die gedragsdimensies waarna gesoek word op 'n onderhoudsbeoordelingsvorm aan te bring. Dit kan deur die personeelbeampte gedoen word. 'n Standaard beoordelingsvorm behoort ontwerp te word waarop daar vir ruimtes voorsiening gemaak word waarin die volgende inligting ingevul kan word:

- Benaming van die vakante pos.

- Naam en posisie van die onderhoudvoerder.

- Datum waarop die onderhoud gevoer word.

- Persoonlikheidsdimensies waarna gesoek word en moontlik die relatiewe gewig wat aan elk hiervan gekoppel kan word.

- Moontlike vrae wat ten opsigte van elke dimensie tydens die onderhoud gevra kan word.

- 'n Beoordeling op 'n skaal ten opsigte van elke gedragsdimensie.

- Opmerkings en bykomende inligting.

Vir elke vakante pos kan die personeelbeampte die gedragsdimensies waarop daar besluit is, op die beoordelingsvorm aanbring en saam met af skrifte van die voltooide aansoekvorm en ander inligtingstukke aan elke onderhoudvoerder voorsien. Die res van die inligting word dan deur hom voltooi. Verskeie soorte beoordelingskale kan oorweeg word, maar die volgende vyfpuntskaal behoort voldoende te wees:

+2 Voldoen in ' $n$ baie sterk mate aan die betrokke vereiste gedragsdimensie.

+1 Voldoen in ' $\mathrm{n}$ redelike mate aan die betrokke vereiste gedragsdimensie.

0 Geen duidelike aanduiding in enige rigting nie.

-1 Voldoen nie heeltemal aan die betrokke vereiste gedragsdimensies nie.

-2 Voldoen geheel en al nie aan die betrokke vereiste gedragsdimensie nie.

'n Groot voordeel van so 'n vorm is dat dit die onderhoudvoerders dwing om vooraf moontlik vrae te identifiseer wat direk verband hou met die gedragsdimensies wat deur die betrokke pos vereis word. 


\section{Voer van die onderhoud}

Dit is nodig dat ' $\mathrm{n}$ atmosfeer geskep word wat bevorderlik is vir die daarstel van goeie rapport tussen die applikant en die onderhoudvoerders sodat die applikant nie psigologies bedreig voel nie en bereid voel om soveel inligting moontlik te verstrek. Meyer en Donaho ${ }^{15}$ stel in hierdie verband voor dat die onderhoud gevoer moet word in 'n lokaal wat privaat, gerieflik en vry van steurings is. Onderhoudvoerders behoort nie agter (deurmekaar) lessenare te sit en 'n gesagsposisie probeer aanneem nie. Maak liewer gebruik van gemaklike stoele by 'n ronde tafel of 'n koffietafel. Applikante behoort vriendelik gegroet en tuisgemaak te word deur eers 'n kort geselsie aan te knoop oor 'n onderwerp van algemene belang. Drake $e^{5, p p .15-20}$ wys egter daarop dat hierdie algemene geselsie ('small talk') nie geforseerd moet voorkom nie en só gekies moet word dat dit 'n logiese inleiding tot die onderhoud is. Direk hierna behoort die onderhoudvoerder kortliks die doel van die onderhoud te skets en daarop te wys dat die applikant vry moet voel om ook vrae te vra. Die onderhoudvoerder moet ook op hierdie stadium aan die applikant noem dat hy moontlik enkele aantekeninge sal maak en dat die applikant vry moet voel om dieselfde te doen.

Wat die benadering tot die keuringsonderhoud betref, kan daar onderskei word tussen 'n meer direktiewe of gestruktureerde benadering en 'n nie-direktiewe of ongestruktureerde benadering. By eersgenoemde soort onderhoud beskik die onderhoudvoerder oor 'n bepaalde lys vrae wat hy vooraf opgestel het en hy wyk nie af van hierdie lys nie. In die geval van die nie-direktiewe of ongestruktureerde onderhoud bestaan geen vooropgestelde lys van vrae nie en ontwikkel die onderhoud geheel en al uit die response van die applikant.

Een van die voordele van 'n gestruktureerde benadering is volgens Robb ${ }^{16}$ dat dit minder tyd in beslag neem as ' $n$ ongestruktureerde benadering. Vrae is gewoonlik meer op die punt af en minder tyd word verspil deurdat relevante inligting bespreek word. Robb ${ }^{16}$ wys ook daarop dat swakker opgeleide onderhoudvoerders meer suksesvol is in die hantering van direktiewe onderhoude as in die hantering van nie-direktiewe onderhoude. Ook Schmitt ${ }^{11, p .275}$ verwys na navorsing deur Carlson, asook deur Schwab en Henneman wat bevestig dat strukturering van die onderhoud lei tot laer beoordelings, maar wel ook tot ' $n$ hoër voorspellingsgeldigheid en 'n groter mate van interbeoordelaarkonstantheid. Volgens Robb ${ }^{16}$ is een van die grootste nadele van die direktiewe of gestruktureerde benadering dat dit kan lei tot onbuigbaarheid en dat belangrike bykomende inligting sodoende verlore kan gaan. Dit kan ook lei tot 'n groter mate van formaliteit tydens die onderhoud wat rapport kan benadeel.

Die ongestruktureerde of nie-direktiewe benadering daarteenoor, hou volgens Robb ${ }^{16}$ die voordeel in dat die totale persoonlikheid van die applikant beoordeel word en nie net sekere gedragsdimensies nie. Drake ${ }^{5, p p \cdot 24-25}$ propageer 'n sogenoemde 'emergence approach' tot onderhoudvoering wat as 'n ongestruktureerde benadering beskou kan word. Hiervolgens benader die onderhoudvoerder die onderhoud sonder 'n voorafopgestelde lys van dié kenmerke waarna hy tydens die onderhoud wil soek. Hy stel voor dat die onderhoudvoerder tydens die onderhoud 'n beeld probeer opbou van hoe die applikant optree en funksioneer en hy probeer dan die kwaliteite van die applikant wat tydens die onderhoud na vore kom, koppel aan die vereistes van die pos. Die grootste tekortkoming van hierdie benadering is egter die feit dat dit hoë eise stel aan die gedragswetenskaplike kennis en vaardighede van die onderhoudvoerder. Bestuurders wat hulle opleiding in ander vakgebiede ontvang het, soos byvoorbeeld in ' $n$ syferkundige of tegniese rigting, is nie altyd in staat om die nie-direktiewe benadering korrek te hanteer nie. Byham ${ }^{12}$ waarsku dan ook teen die neiging van onderhoudvoerders om 'amateur psigiater' te probeer speel.

Die oplossing lê waarskynlik in 'n benadering wat sover moontlik die meeste voordele van die gestruktureerde sowel as ongestruktureerde onderhoud probeer insluit. Glueck ${ }^{17}$ stel om hierdie rede die semi-gestruktureerde onderhoud voor en sê die volgende in hierdie verband:

This approach combines enough structure to facilitate the exchange of factual information with adequate freedom to develop insights

'n Soortgelyke benadering word deur Orpen ${ }^{7 . p p .62-68}$ voorgestel en hy verwys in hierdie verband na die "patterned interview'. Hiervolgens word vrae vooraf geidentifiseer wat dien as gids vir die onderhoudvoerder en hy stuur dan die onderhoud in die verlangde rigting met die oog op verdere verkenning.

Daar kan dus voorgestel word dat onderhoudvoerders by keuringsonderhoude van so 'n semi-gestruktureerde benadering gebruik maak en as basis hiervoor die beoordelingsvorm waarna daar reeds verwys is, gebruik. Onderhoudvoerders kan dan in enige volgorde vrae vra wat op die vooraf-geidentifiseerde gedragsdimensies gerig is en enige toepaslike bykomende inligting wat tydens die onderhoud na vore kom, invul in die ruimte wat daarvoor voorsiening maak.

' $n$ Verdere aspek van belang, is die spesifieke tegniek wat deur onderhoudvoerders toegepas word by die vra van vrae. Pursell, Campion en Gaylord ${ }^{18, p .910}$ doen die volgende wenke aan die hand in die geval van 'n meer gestruktueerde soort onderhoud:

- Vrae moet akkuraat en volledig wees en op 'n ondubbelsinnige wyse gestel word.

- Vrae moet direk betrekking hê op die vereistes van die vakante pos en nie net ter wille van interessantheid gevra word nie.

- Vrae moet gemik wees op kennis, houdings of vaardighede waaroor die applikant vooraf moet beskik en nie op die wat later aangeleer kan word nie.

- Meer tyd moet bestee word aan vrae oor dié aspekte van die pos wat later die grootste hoeveelheid van die posbekleër se tyd in beslag sal neem.

- Vrae moet gemik wees op die vlak van kompleksiteit wat van toepassing is op die verskillende aktiwiteite in die pos.

Wat die aard van vrae betref wat tydens ' $n$ keuringsonderhoud gevra kan word, onderskei Wanous ${ }^{8 . p .110}$ tussen oopeinde vrae, die stel van 'n hipotetiese situasie, spesifieke vrae en spanningsvrae.

Oop-einde vrae kan nie slegs met ' $n$ ' $j a$ ' of ' $n$ 'nee' beant- 
woord word nie en hou die voordeel in dat die applikant dus meer inligting verstrek. Die stel van 'n hipotetiese situasie sluit nou hierby aan en stel die onderhoudvoerder in staat om objektief die applikant se denkproses waar te neem. Dit hou volgens Michaels, pp. 199-224 ook die voordeel in dat dit so gestel kan word dat dit direk verband hou met die pos.

Wat spesifieke vrae betref is dit baie belangrik dat die vrae nie op 'n leidende wyse gestel word sodat dit vir die applikant duidelik is watter antwoord hy behoort te gee nie. Sulke vrae behoort beperk te word tot verifieerbare biodata-aspekte soos byvoorbeeld ouderdom, huwelikstaat, aantal vorige werkgewers, ensovoorts, met dien verstande dat dit nie reeds op die aansoekvorm deur die applikant beantwoord is nie. Daar kan ook sterk aanbeveel word dat onderhoudvoerders eers inligting probeer inwin voordat inligting verstrek word. Sodoende word daar in 'n groot mate voorkom dat die applikant antwoorde verstrek om die onderhoudvoerder positief te beïndruk, maar wat nie 'n betroubare weergawe van sy werklike gevoelens is nie.

Spanningsvrae moet volgens Mondy en Noe ${ }^{19}$ slegs deur goedopgeleide en vaardige onderhoudvoerders gevra word en wel slegs in gevalle waar reaksies onder druk 'n uiters belangrike onderdeel vorm van die vakante pos. Spanningsonderhoude moet slegs gevoer word indien inligting omtrent hierdie betrokke gedragsdimensie nie op ' $n$ ander wyse, soos byvoorbeeld deur middel van 'n navraag by vorige werkgewers, ingesamel kan word nie.

'n Aspek wat ook van belang is tydens die onderhoud is die wyse waarop die onderhoudvoerder reageer teenoor die applikant se antwoord op sy vrae. In die eerste plek is dit belangrik dat die onderhoudvoerder aandagtig luister na wat die applikant sê en aan die applikant toon dat hy belangstel in dit wat die applikant sê (Flippo ${ }^{2}$ ). 'n Verdere wenk wat deur Drake ${ }^{5, p .34}$ gegee word, is dat onderhoudvoerders nie tydens die onderhoud verbaal of deur middel van gesigsuitdrukking negatief moet reageer op ongunstige inligting wat deur die applikant verstrek word nie en veral nie in ' $n$ argument betrokke moet raak nie. Om slegs te luister is nie altyd voldoende nie. Flippo ${ }^{2, p .144}$ wys daarop dat navorsing toon dat waar notas geneem word tydens onderhoude, daar 'n hoër mate van interbeoordelaar-betroubaarheid voorkom. Hy waarsku egter dat die neem van notas tydens die onderhoud rapport kan benadeel en daarom sou 'n voorafvoorbereide beoordelingsvorm soos hierbo bespreek 'n goeie oplossing wees.

Die onderhoud moet ook behoorlik afgesluit word. Drake $^{5, p .112}$ stel voor dat die afsluiting van die onderhoud moet bestaan uit twee stappe, naamlik die beëindiging van die gesprek en die verkoop van die organisasie. Wanous ${ }^{8, p p .106-108}$ se studie met betrekking tot die bemarking van die organisasie het egter aangetoon dat die aspekte wat applikante gunstig beïndruk nie net tot ' $n$ paar indrukwekkende woorde aan die einde van die onderhoud beperk is nie, maar dat die gedrag en houding van die onderhoudvoerder tydens die hele onderhoud deurslaggewend is. Wat die amptelike beëindiging van die gesprek betref, kan die onderhoudvoerder die inisiatief neem deur aan die applikant te noem dat hy geen verdere vrae het nie en vra of laasgenoemde nog vrae het wat onbeantwoord is. Die onderhoudvoerders moet dan die applikant bedank vir sy besoek en aan hom ' $n$ aanduiding gee wanneer en op welke wyse hy 'n finale antwoord kan verwag. Die onderhoudvoerder kan ook op nie-verbale wyse aandui dat die onderhoud beëindig is soos byvoorbeeld deur op sy horlosie te kyk, op te staan, na die deur te beweeg, ensovoorts.

\section{Evaluering van die applikant}

Die stappe wat hierbo voorgestel is by die voorbereiding vir die onderhoud behoort die evalueringsproses te verbeter en te vergemaklik. Die opstel van ' $n$ lys van verlangde gedragsdimensies in die lig van die vereistes van die vakante pos met die doel om as riglyn te dien vir 'n semi-gestruktueerde onderhoud, behoort op grond van Dessler ${ }^{13}$ en Schmitt ${ }^{11, p p .272-275}$ se bevindinge by te dra tot 'n hoër mate van interbeoordelaar-betroubaarheid. Omdat die onderhoudvoerder self ten nouste by bogenoemde stappe betrokke was, beskik hy oor meer volledige inligting oor die pos en die vereistes daarvan en behoort hy in staat te wees om geldiger vrae tydens die onderhoud te vra. Dit verskaf dan weer aan hom 'n groter hoeveelheid van die toepaslike inligting wat benodig word om die applikant te evalueer.

Die betrokkenheid van die onderhoudvoerder by die identifisering van die verlangde gedragsdimensies behoort vooropgestelde idees omtrent stereotipes in 'n groot mate te voorkom en mee te bring dat alle applikante meer objektief teen die betrokke gedragsdimensies beoordeel word. Die gebruik van die beoordelingsvorm waarop die verlangde gedragsdimensies aangebring is, sal daartoe bydra dat sterk punte sowel as tekortkominge van alle applikante ten opsigte van hierdie dimensies meer objektief geidentifiseer en gekwantifiseer word. Hieruit behoort daar dan bepaal te kan word watter kandidaat die geskikste is en sodoende word die foute verbonde aan die intuitiewe keuse van 'n ideale persoon of stereotipe in 'n groot mate voorkom.

Die gebruik van die beoordelingsvorm soos hierbo bespreek, sal meehelp om die kontras-effek uit te skakel. In plaas daarvan dat applikante met mekaar vergelyk word, word hulle nou gemeet aan 'n buitestandaard soos bepaal deur die vereistes van die vakante pos. Die voordeel hiervan is dat daar gevind kan word dat meer as een applikant suksesvol kan wees en alternatiewe keuses gemaak kan word indien ' $n$ applikant hom onttrek of nie die aanstelling aanvaar nie. Daar sou ook gevind kan word dat geen van die applikante in 'n aanvaarbare mate aan die posvereistes voldoen nie en dat bykomende applikante gewerf moet word eerder as om die beste uit 'n groep swak applikante aan te stel, veral in gevalle waar daar ' $n$ mate van druk is om 'n vakature so spoedig moontlik te vul. Hierdie benadering sal ook die tekortkominge van die suksesvolle applikant uitwys en werkgewers in staat stel om vooraf te bepaal watter opleiding gegee behoort te word.

Verskeie van die ander foute wat gemaak word by die evaluering van applikante, soos byvoorbeeld die neiging om eerste indrukke swaarder te laat weeg of om te veel betekenis te heg aan negatiewe inligting, behoort ook in 'n groot mate uitgeskakel te word wanneer alle applikante aan die hand van die semi-gestruktueerde onderhoud deur middel van die beoordelingsvorm in kwantifiseerbare terme geëvalueer word. Hierdie benadering sal volgens Schmitt ${ }^{11, p p .265-283}$ die onderhoudvoerders dwing om aandag te gee aan alle in- 
ligting wat die applikant verstrek en om nie net te soek na negatiewe inligting nie.

Die feit dat die onderhoudvoerders baie nou by die beplanningsfase betrokke is, sal daartoe meehelp dat onderlinge verskille tussen beoordelaars oor waarna hulle soek en hoe betekenisvol ' $n$ bepaalde gedragsdimensie is, vroegtydig beperk word en dat moontlike ongeldige persoonlike voorkeure van die onderhoudvoerders betyds uitgeskakel word. Sodoende sal onderhoudvoerders die onderhoudsituasie met minder ongeldige vooropgestelde idees benader.

'n Verdere voordeel verbonde aan bogenoemde benadering tot die evaluering van applikante is dat daar tydens die beplanningsfase reeds bepaal kan word watter toepaslike inligting op 'n ander meer betroubare wyse ingesamel kan word as deur middel van die onderhoud. Dit sal die probleem voorkom waarteen Byham, ${ }^{12}$ Dunette ${ }^{6, p .65}$ en ander waarsku, naamlik die neiging van onderhoudvoerders om te veel waarde te heg aan die onderhoud as keuringsinstrument.

Wat die prosedure van evaluering betref, kan aanbeveel word dat onderhoudvoerders die beoordelingsvorms ten opsigte van elke applikant direk na die afhandeling van die onderhoud voltooi sonder om dit onderling te bespreek. Die dag nadat die onderhoude gevoer is kan die betrokke personeelbeampte dan reël dat die onderhoudvoerders byeenkom en hulle beoordeling bespreek. Dit behoort voldoende tyd te laat vir die onderhoudvoerders om weer oor hulle beoordelings te besin en retrospektief en gewoonlik met 'n groter mate van objektiwiteit 'n finale beoordeling te doen. Op grond hiervan word daar dan deur die onderhoudvoerders gesamentlik tot 'n finale besluit gekom, maar die hoof van die departement waarbinne die vakante pos is en wat ook een van die onderhoudvoerders sou moes wees, beskik steeds oor die finale gesag om hierdie besluit te verwerp of te bekragtig.

\section{Slotopmerkings}

Die benadering tot onderhoudvoering soos hierbo voorgestel vereis dus dat die onderhoudvoerders by ten minste drie geleenthede byeenkom, naamlik tydens die beplanningsfase, by die voer van die onderhoude en by die evalueringsfase. Die voordele hieraan verbonde sowel as aan die prosedure wat voorgestel is met betrekking tot die identifisering van sleutelaktiwiteite in die pos en die vereiste gedragsdimensies wat as basis gebruik word vir 'n beoordelingsvorm, regverdig sekerlik die tyd wat dit vereis van bestuurders en personeelbeamptes. Geen bestuurder kan suksesvol fungeer sonder bekwame personeel in sy span nie en daarom is elke bestuurder dit aan homself en sy organisasie verskuldig om op professionele wyse te werk te gaan by die keuring van sy personeel sodat hy applikante kan identifiseer wat hom sal help om die eise wat aan hom gestel word effektief na te kom.

\section{Summary}

The selection interview still remains one of the most important and most commonly used selection techniques. During their formal training personnel officials are normally taught how to conduct selection interviews in a professional and effective way. However, the final respon- sibility for the selection decision still rests with the line manager, but he often lacks the skills necessary to conduct a good selection interview. The result of this is that a highly intuitive and risky decision is taken.

It is furthermore important to note that the selection interview is much more than only a selection aid for prospective employers because it also serves as a very important device for marketing the organization to prospective employees. Not only does the interviewer decide on the basis of the information received during the interview whether the applicant is exceptable or not, but the applicant himself forms an opinion of the organization which largely determines his decision whether to except or refuse an offer for employment.

In this article the most important errors which interviewers make, are discussed. These errors relate in the first instance to the way in which selection interviews are conducted and the resulting shortcomings in communication which have a negative effect on the availability of information requested for decision-making. Secondly, errors are often made in respect of the interpretation and evaluation of this information. Examples of the most common errors which are discussed are the following:

- The primacy effect which is the tendency of interviewers to form a final and definite opinion of the applicant too soon during the interview.

- The tendency of interviewers to attach a higher level of significance to negative information than to positive information.

- The tendency of interviewers to have pre-conceived ideas regarding a stereotype whom they think will be the only successful candidate for a particular vacancy.

- Individual characteristics of interviewers such as beliefs, attitudes, experiences etc., which bias their evaluations of applicants.

- Lack of proper preparation for the interview which often results in incomplete and unreliable information being obtained as the basis for the selection decision.

The second part of this article deals with a proposed procedure which should result in largely eliminating the abovementioned errors. This procedure is discussed in terms of the three major phases in the interview process, namely preparation for the interview, the interview itself and the evaluation of applicants.

During the preparation phase, the drawing up of a man specification which is based on a job discription, plays an important role. This leads to the identification of certain required dimensions of behaviour in respect of which information is seeked during the interview. These dimensions of behaviour also form the basis of an interview appraisal form and help in planning relevant questions which could be used during the interview.

As far as conducting the interview is concerned, a semistructured approach is suggested and ways in which an interviewer can create an atmosphere which is conducive to good rapport, are dicussed. Suggestions are also made in respect of aspects such as techniques of questioning, types of questions, reaction of interviewers etc.

In the evaluating phase, the interview appraisal form plays a major role. Its application is therefore discussed in detail and suggestions are made which should lead to a more valid and reliable appraisal of applicants. 
The article specifically deals with the role of the line manager during all three above-mentioned phases. It is stressed that his involvement in respect of each of these is essential to enable him to make the best possible decision in selecting his team of subordinates.

\section{Verwysings}

1. Michaels, D.T. Seven questions that will improve your managerial hiring decisions. Personnel J., Maart 1980, 59(3), pp. $199-224$.

2. Flippo, E.B. Personnel Management. New York: McGraw-Hill, 1980, p. $143-144$.

3. Amptelike Jaarboek van die Republiek van Suid-Afrika. Johannesburg: Van Rensburg. 1982, p.444.

4. Bendix, D.W.F. \& Swart, S.M. (s.j.) A survey of employment conditions in the Republic of South Africa. Ongepubliseerde verslag.

5. Drake. J.D. Interviewing for Managers. AMA, 1972 , pp. $5-112$.

6. Dunnette, M.D. Personnel Selection and Placement. Belmont: Wadsworth, 1966, pp.7-88

7. Orpen, C. The Principles of Personnel Psychology. Kenwyn: Juta 1979, pp.60-68.

8. Wanous, J.P. Organizational Entry: Recruitment, Selection and Socialization of Newcomers. Reading: Addison-Wesley, 1980, pp. $106-142$.

9. Cascio, W.F. \& Awad, E.M. Human Resources Management:
An Information Systems Approach. Reston: Reston Publications, 1981, pp.247-250.

10. Latterell, J.D. Planning for the selection interview. Personnel J., Julie 1979, 58(1), pp.466- 480 .

11. Schmitt, N. Social and situational determinants of interview decisions: Implications for the employment interview. In Schneier, C.E. en Beatty, R.W. Personnel Administration Today. Reading: Addison-Wesley, 1978, pp.265-283.

12. Byham, W.C. Help managers find the best candidate for the job with assessment centre techniques. Training, November $1979,16(11)$, pp.64-73.

13. Dessler, G. Personnel Management: Modern Concepts and Techniques. Reston, Reston Publications, 1978, p.86.

14. Hollandsworth, J.G., Kazelskis, R., Slevens, J. \& Dressel, M.E. Relative contributions of verbal articulative and nonverbal communication to employment decisions in the job interview setting. Personnel Psychol., 1979, 32, pp.359-367.

15. Meyer, J.L. \& Donaho, M.W. Get the Right Person for the Job. Englewood Cliffs: Prentice-Hall, 1979, p.157.

16. Robb, W.D. Interviewing efficiency: Speed and effectiveness in employee selection. Adv. Manage. J., 1980, 45(2), pp.24-30.

17. Glueck, W. Personnel: A Dragnostic Approach. Dailas: Business Publications, 1978, p.204.

18. Pursell, E.D., Campion, M.A. \& Gaylord, S.R. Structured interviewing: Avoiding selection problems. Personnel J., November 1980, 59(11), pp. $907-912$.

19. Mondy, R.W. \& Noe, R.M. Personnel: The Management of Human Resources. Boston: Allyn Bacon, 1981, p.173. 